\title{
Climate change assessment for a small island: a Tahiti downscaling experiment
}

\author{
M. Hopuare ${ }^{1,2, *}$, M. Pontaud ${ }^{2}$, J. -P. Céron ${ }^{3}$, M. Déqué $^{2}$, P. Ortéga ${ }^{1}$ \\ ${ }^{1}$ GePaSud Laboratory, Tahiti, French Polynesia \\ ${ }^{2}$ CNRM GAME UMR 3589, Météo France/CNRS, Toulouse, France \\ ${ }^{3}$ Direction de la Climatologie, Météo France, Toulouse, France
}

\begin{abstract}
This study addresses the projected 21st century changes in austral summer precipitation and future precipitation anomalies related to El Niño Southern Oscillation (ENSO) for a South Pacific island: Tahiti, French Polynesia. An approach involving 2 successive downscaling steps is proposed here as a first attempt to simulate precipitation over a small orographic island. First, the $50 \mathrm{~km}$ mesh global atmospheric model ARPEGE is forced by bias-corrected sea surface temperatures (SSTs) from a CMIP5 scenario. This model drives the limited area model ALADIN. The final $12 \mathrm{~km}$ mesh regional simulation coarsely captures the island of Tahiti. Historical and scenario runs (RCP4.5 and RCP8.5) are therefore available at the island scale. Linking station data and historical model outputs using quantile-quantile plots allows a correction of the biases of the regional simulation and an assessment of precipitation changes over the 21st century. For both scenarios, mean austral summer precipitation tend to increase over the century on the south-east side of Tahiti, following the present El Niño-like precipitation pattern. This trend could be a local manifestation of the large-scale drift of the tropical Pacific Ocean towards an El Niño-like spatial structure. This drift is indeed verified in the SST fields. Then, superimposed upon this slowly evolving mean state, future El Niño events would cause positive precipitation anomalies, whereas future La Niña events would cause negative precipitation anomalies. However, in the last period of RCP8.5, future El Niño events do not seem to affect precipitation anymore, suggesting a damping of the warm events, probably due to a warmer mean state.
\end{abstract}

KEY WORDS: South Pacific · Regional climate simulation

\section{INTRODUCTION}

People living in Pacific islands are already experiencing changes in their climate, such as higher temperatures, shifts in precipitation regimes, changing frequencies of extreme events and rising sea levels (Stocker et al. 2013). These changes are affecting the local population's well-being, water resources management, security and habitable zone. Although sea level rise is a major concern for Pacific islands (Becker et al. 2012), the focus is on the atmospheric component, (1) for practical data availability reasons - precipitation gauges provide observed datasets long enough to conduct climate change studies and (2) because the atmospheric component holds another crucial aspect for local populations: future water resources.

Situated in the middle of the south Pacific Ocean, Tahiti, the largest island of French Polynesia ( 30 x $30 \mathrm{~km}^{2}$ ), is a volcanic island with steep topography in its central part (the highest point reaches $2241 \mathrm{~m}$ above the sea level). Wind-swept by the trade winds all year long, the south-east side of Tahiti is prone to orographic precipitation and, hence, is wetter than the north-west part. The island is also located at the south-eastern edge of the climatological South Paci- 
fic Convergence Zone (SPCZ), which can be seen as a persistent cloud band stretching from Papua New Guinea to French Polynesia. Precipitation regimes in Tahiti are therefore linked to the migrations of the SPCZ, which vary from intraseasonal to interdecadal timescales (Folland et al. 2002, Vincent et al. 2011, Matthews 2012, Salinger et al. 2013). Hopuare et al. (2015) have recently described Tahiti's seasonal precipitation cycle, which is composed of 2 main seasons. The wet season from November to April is consistent with the diagonal extension of the SPCZ towards Tahiti. The dry season is from May to October.

The El Niño Southern Oscillation (ENSO) and the Interdecadal Pacific Oscillation (IPO) involve precipitation anomalies on interannual to interdecadal time scales. The North Pacific spatial pattern of the IPO is similar to the Pacific Decadal Oscillation (PDO), which is described for the North Pacific only (Mantua et al. 1997). Considering the IPO is defined for the whole Pacific basin, it is best suited to study interdecadal variability in Tahiti. For instance, the positive phase of the IPO ( 20 yr long) is known to imply a northward shift of the SPCZ (Folland et al. 2002), which lies closer to Tahiti and generates positive precipitation anomalies over the entire island (Hopuare et al. 2015). Conversely, the negative phase of the IPO induces a southward shift of the SPCZ and, hence, lower precipitation records for Tahiti. Strong El Niño events, more frequent during the positive IPO phase, favour a quasi-zonal orientation of the SPCZ along the equator, which alters the trade winds trajectory and causes anomalous positive precipitation on the south-east side of Tahiti. In the case of La Niña, the SPCZ migrations and the role of IPO are less clear.

Although global climate models (GCMs) are particularly helpful tools for climate change study, because they provide global climate scenarios, they still fail to simulate realistic spatial patterns of precipitation in the South Pacific (Brown et al. 2013). They are hence unable to adequately resolve precipitation signals at the island scale. Downscaling is a necessary step to derive high-resolution information from the coarse resolution of the GCMs. In the last few decades, many downscaling techniques have been set up and documented. Two main categories have emerged: (1) statistical downscaling uses empirical relationships between climate model outputs and historical observed data (Hewitson \& Crane 1996, Wilby et al. 2004); (2) dynamical downscaling consists of the use of a regional climate model (RCM hereafter) (Fowler et al. 2007). When nested in a GCM, an RCM pro- vides a response that is in coarse agreement with the host GCM but with spatially consistent details. Recently, a joint effort of the international scientific community toward a coordination of regional climate downscaling has led to the CORDEX experiment, inspired by the CMIP5 framework. Unfortunately, the central Pacific region is not included in any CORDEX domain, which means no downscaled experiments at $\sim 50 \mathrm{~km}$ are available over Tahiti.

Despite increased resolution, the need to correct biases in RCM projections is well known (Christensen et al. 2008), and the influence of such biases on impact modeling (hydrological and crop) has been the topic of many studies (Wood et al. 2004, Baigorria et al. 2007, Ghosh \& Mujumdar 2009, Teutschbein \& Seibert 2010, among others). These researchers argued that the application of model outputs to impact models may be unsuitable unless model outputs are corrected. Statistical downscaling is inherently bias-free because bias correction is included in the statistical 'learning' process.

Several techniques for adjusting biases in GCM and RCM daily precipitation have been published. These techniques can be grouped into 4 classes: (1) linear (e.g. using a seasonally and spatially varying change factor; Lenderink et al. 2007), (2) nonlinear (e.g. using a seasonally and spatially varying change factor and exponent; Leander \& Buishand 2007), (3) distribution-based quantile mapping (e.g. $\gamma$ distribution; Hay \& Clark 2003, Déqué 2007, Piani et al. 2010, Bennett et al. 2014) and (4) distribution-free quantile mapping (e.g. empirical distribution; Wood et al. 2002, 2004, Ashfaq et al. 2010). In the present study, distribution-based quantile mapping has been employed.

The scope of the paper arose from the need to assess the impacts of climate change over a remote and isolated South Pacific island, Tahiti, French Polynesia. As mentioned above, in the CORDEX share of the world, none of the domains encompass Tahiti and French Polynesia. Therefore, the present method was developed to overcome this lack of regional climate simulations over the region. In this study, a 2 step downscaling method is proposed to spatially resolve the island of Tahiti, firstly from $150 \mathrm{~km}$ to $50 \mathrm{~km}$ and then from $50 \mathrm{~km}$ to $12 \mathrm{~km}$ resolution. Observed precipitation records are used to build a statistical relationship between observed and RCM precipitation in the historical simulation. This relationship is then applied to 21st century greenhouse gas (GHG) emission scenario runs (RCP4.5 and RCP8.5) to derive Tahiti's precipitation projections up to 2100 . 


\section{DOWNSCALING STRATEGY}

A dynamical downscaling strategy involving 3 simulations (of which 1 is an RCM) was set up. Using the finest resolution (i.e. $12 \mathrm{~km}$ ) available for the RCM, a few land grid points confirm the presence of the island. Therefore, the local orographic effect is captured, and soil characteristics are allocated to the land grid points. Obviously, the present method can also be applied to any other small island country that does not benefit from a CORDEX domain or which is too small for the standard CORDEX resolution $(50 \mathrm{~km})$.

The first step consists of the use of a CMIP5 model, in this case the CNRM-CM5, which translates GHG and aerosol concentration scenarios into SST for all oceans. Its horizontal resolution is about $150 \mathrm{~km}$. A first downscaling is performed using the global atmospheric model ARPEGE at $50 \mathrm{~km}$ resolution, (see Section 3.2). The SST fields, modelled by the CNRM-CM (historical and scenario runs), are used as boundary conditions for ARPEGE, after the application of a SST bias-correction procedure (see Section 3.4). Even with a $50 \mathrm{~km}$ mesh, the island of Tahiti remains unresolved.

A second downscaling is then produced by nesting the RCM ALADIN (12 km mesh) in ARPEGE $50 \mathrm{~km}$. This higher-resolution simulation allows the representation of Tahiti by up to 6 land grid-points.

The new $12 \mathrm{~km}$ mesh simulation over historical and 21st century periods provides a suitable dataset to perform a study of climate change. It should be noted that the RCM carries its own intrinsic biases in addition to the systematic biases inherited from the global host model.

The left part of the diagram displayed in Fig. 1 shows the statistical linkage established over the historical period between modelled and available observed precipitation. This linkage is assumed to remain unchanged throughout the 21st century period,

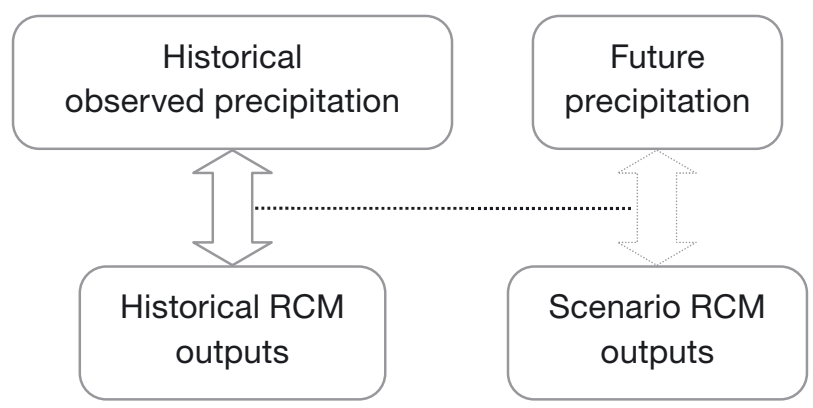

Fig. 1. Model and observation relationship over the past and future although it is subject to debate. A previous work of Christensen et al. (2008) indeed suggested that biases may not be invariant in a warming climate. Future changes of precipitation along the 21st century are derived from modelled changes of precipitation using the statistical relationship established (right part of the diagram of Fig. 1).

\section{TOOLS AND DATASETS}

\subsection{The global climate model CNRM-CM}

The CNRM-CM (Centre National de Recherches Météorologiques-Coupled Model) version used is the latest version of the general circulation model CNRM-CM5.1. A description of this model is available from Voldoire et al. (2013). CNRM-CM5.1 includes the atmospheric model ARPEGE (Action de Recherche Petite Echelle Grande Echelle)-Climat v5.2, the ocean model NEMO (Nucleus for European Modelling of the Ocean) v3.2 (Madec 2008), the land surface scheme ISBA (Interaction Soil Biosphere Atmosphere) (Noilhan \& Planton 1989, Noilhan \& Mahfouf 1996) and the sea ice model GELATO (Global Experimental Leads and Ice for Atmosphere and Ocean) (v5) (Salas-Mélia 2002).

The land surface scheme ISBA has been externalised from the atmospheric model through the SURFEX (SURFace EXternalisée) platform. The total run-off simulated by SURFEX feeds the TRIP (Total Routing Integrating Pathways) river routing model. All the components are put together through the OASIS (Ocean Atmosphere Sea Ice Soil) coupler.

\subsection{The ARPEGE $50 \mathrm{~km}$ atmospheric climate model}

As a first atmospheric downscaling, we use the atmospheric spectral model ARPEGE $50 \mathrm{~km}$ that uses a triangular truncation T359, which corresponds to a horizontal resolution of about $50 \mathrm{~km}$. The model uses a hybrid $\sigma$-pressure vertical coordinate discretized onto 31 vertical levels, as in its CNRM-CM component.

The main characteristics are:

- the statistical cloud scheme developed by Ricard \& Royer (1993), which is used to compute stratiform cloud fraction, stratiform liquid water content and coefficients of turbulent vertical mixing,

- the statistical precipitation scheme described by Smith (1990), which computes large-scale precipitation, 
- the deep convection scheme described by Bougeault (1985), in which convection is parameterized by a mass-flux scheme where the vertical ascent in the cloud is compensated by a large-scale subsidence, and

- the land surface scheme ISBA.

The radiation transfer parameterization is the radiation package of Morcrette (1990), and the exchange coefficients at the air-water interface are derived from Louis functions (Louis 1979). These last 2 parameterizations differ from the ARPEGE component in CNRM-CM, for practical reasons. This choice does not have a strong impact on the ARPEGE climate.

Then, the global atmospheric ARPEGE $50 \mathrm{~km}$ model fields are used as lateral boundary conditions for the RCM ALADIN-Climate. A 6-hourly lateral forcing by vorticity, divergence, temperature, relative humidity and surface pressure logarithm is performed. ARPEGE and ALADIN share the same semiimplicit semi-Lagrangian dynamics.

\subsection{The regional climate model ALADIN}

The RCM used, ALADIN, is a spectral limited area model developed for short-range regional weather forecasting (Bubnová et al. 1995, Horányi et al. 1996).

Horizontally, the model domain represents an area with uniform spacing between the grid cells in both horizontal directions. In this study, the 'Tahiti' domain used covers $15.5^{\circ} \mathrm{S}$ to $20.5^{\circ} \mathrm{S}$ latitude and $152.5^{\circ} \mathrm{W}$ to $147.5^{\circ} \mathrm{W}$ longitude (Fig. 2a). The orography of Tahiti, as seen in ALADIN, is altered; indeed, the real highest point of Tahiti reaches $2241 \mathrm{~m}$, whereas in ALADIN it is only $992 \mathrm{~m}$ (Fig. 2b). Also, only 6 grid cells are considered as 'land' points. The neighbouring grid cells are therefore 'sea' points at high altitudes. The tangent version of the Lambert conformal projection is used. The vertical coordinate system is the same as in ARPEGE. The large-scale meteorological information is forced on the inner model solution by a classical relaxation scheme (Davies 1976). With the application of an additional relaxation zone, the method is also capable of damping the artificial reflection and transmission of small-scale waves on the boundaries of the domain of interest. Model prognostic variables are zonal and meridional wind components, temperature, specific humidity and surface pressure.

The physical parameterization package of the ALADIN-Climate model corresponds to that of ARPEGE $50 \mathrm{~km}$ global model. Although it has a nonhydrostatic version, ALADIN has been used here as a hydrostatic model.

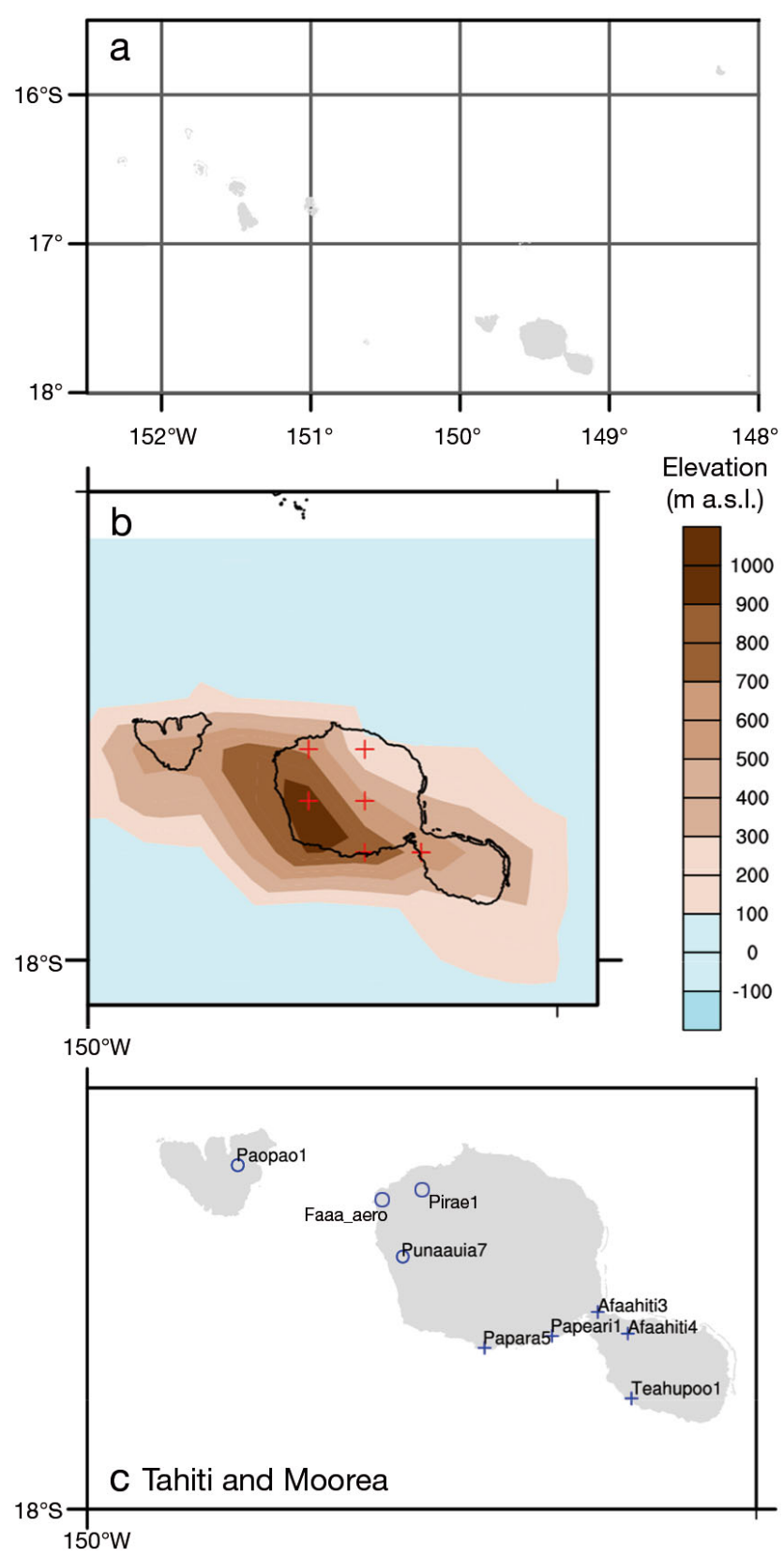

Fig. 2. (a) The ALADIN domain over Tahiti at $12 \mathrm{~km}: 45 \times 45$ grid cells. (b) The topography of Tahiti as seen by ALADIN in meters above sea level. 'Land' grid-points are represented by red crosses; the neighbouring grid-points are considered as 'sea' grid-points aloft. (c) Location of the precipitation gauges over Tahiti and Moorea. Windward stations are represented by crosses and leeward stations by open circles

\subsection{The SST bias correction}

A common bias of global coupled models participating in IPCC's 5th Intercomparison Project concerns the South Pacific Convergence Zone (SPCZ) (Dai 2006, Brown et al. 2013). Instead of stretching 
towards French Polynesia, the convergence zone is extending zonally towards South America. The consequent overestimated precipitation signal in the far eastern Pacific just south of the equator is called the double-ITCZ syndrome. Oueslati \& Bellon (2013) showed with the CNRM-CM model that an increase in lateral convective entrainment improves the southeast orientation of the SPCZ. However, these improvements are made at the expense of precipitation amounts in the convergence zone that are overestimated, particularly in the case of the atmospheric-only experiment (AMIP) of the CNRM-CM. Hence, no calibration of lateral convective entrainment has been made in this study. In addition, the double-ITCZ syndrome is often associated with a cold bias over the equatorial cold tongue that extends too far into the western part of the basin. Even though atmospheric models have been pointed out to be the cause of this spurious SST pattern, coupled ocean-atmosphere feedbacks also play a significant role by increasing it. Indeed, Lin (2007) showed the impacts of the SST and wind-induced surface fluxes feedback, the SST and stratus feedback and the SSTgradient and trade-wind feedback associated with vertical upwelling on the erroneous SST signal. In the present method, these feedbacks are suppressed by considering solely the atmospheric component of the earth system.

To assess the impacts of global warming on Tahiti's climate up to 2100, SSTs from the historical run of CNRM-CM and from 2 GHG emission scenarios, the RCP4.5 and RCP8.5 runs, are used in this study. As seen above, the erroneous SST pattern is amplified by ocean-atmosphere feedback. A correction method is thus applied to prescribe boundary conditions that are as close to the observations as possible. An observed SST climatology has been calculated on the 1958-2001 period based on SST datasets used for ERA 40 reanalysis (HadISST and Reynolds).

The coupled climatological error $E$ is defined as the difference between CNRM-CM SST historical climatology and observed SST 1958-2001 climatology (computed for each grid cell of the global SST field). The error $E$ has 12 fields, 1 for each month of the year. This mean error is then removed from the model SST. For example, the mean January error is removed from all the January months of the historical run. To assess the amplitude of the error along the equator, the spatial mean of the error in seasonal average and for 3 boxes from west to east (Westbox: $160^{\circ}$ to $170^{\circ} \mathrm{W}, 5^{\circ} \mathrm{N}$ to $5^{\circ} \mathrm{S}$; Centerbox: $140^{\circ}$ to $130^{\circ} \mathrm{W}, 5^{\circ} \mathrm{N}$ to $5^{\circ} \mathrm{S}$ and Eastbox: $90^{\circ}$ to $80^{\circ} \mathrm{W}, 5^{\circ} \mathrm{N}$ to $5^{\circ} \mathrm{S}$ ) of the basin is computed. The error is greatest in the Eastern Pacific with $+1.2^{\circ} \mathrm{C}$ in DJF to $+2.3^{\circ} \mathrm{C}$ in JJA. In the western Pacific, the error reaches $-1^{\circ} \mathrm{C}$ in DJF and $-0.8^{\circ} \mathrm{C}$ in JJA. The SST error is lowest in the Central Pacific: -0.2 in DJF and -0.6 in JJA. An important assumption made is that $E$ remains the same throughout the historical and RCP periods, which may not hold at the end of the 21st century (Meehl et al. 2007, Milly et al. 2008). Finally, the ARPEGE $50 \mathrm{~km}$ atmosphere model is forced by interpolated (150 to $50 \mathrm{~km}$ ) bias-corrected SSTs from the global coupled model CNRM-CM.

An improvement of the SPCZ position is achieved in austral summer (Fig. 3a-c) thanks to the SST bias correction. The GPCP dataset (Fig. 3a) allows the comparison of simulated austral summer precipitation between CNRM-CM5 and ARPEGE $50 \mathrm{~km}$. Despite a slight overestimation of precipitation in the tropical Pacific, the SPCZ spatial extension is better simulated in ARPEGE $50 \mathrm{~km}$ (Fig. 3c) than in CNRMCM5 (Fig. 3b). The spurious eastward extension of the convergence zone south of the equator is reduced in the eastern Pacific, but its orientation is still too zonal in the central Pacific. Furthermore, no progress has been achieved for austral winter. For this reason, the focus will be put on austral summer, which is the wet season and corresponds to the maximum amplitude of ENSO.

\subsection{Observational precipitation datasets}

A newly available high-quality dataset is used to conduct this study (courtesy of Météo France Regional Service in Tahiti). Homogenized monthly precipitation amounts from 9 meteorological stations over Tahiti and Moorea were made available by the meteorological service of French Polynesia. The records, which have undergone the homogenization procedure described by Caussinus \& Mestre (2004), span the period from 1961 to 2011. The 9 stations are shown in Fig. 2c. The stations are not regularly distributed; the majority of them are located on the western part of the island and mainly on the coastline. An analysis of Tahiti's observed precipitation variability from seasonal to interdecadal time scales is available from Hopuare et al. (2015).

\section{RCM PRECIPITATION CORRECTION OVER THE HISTORICAL PERIOD}

To assess future changes of precipitation based on future modelled precipitation, the linkage between 

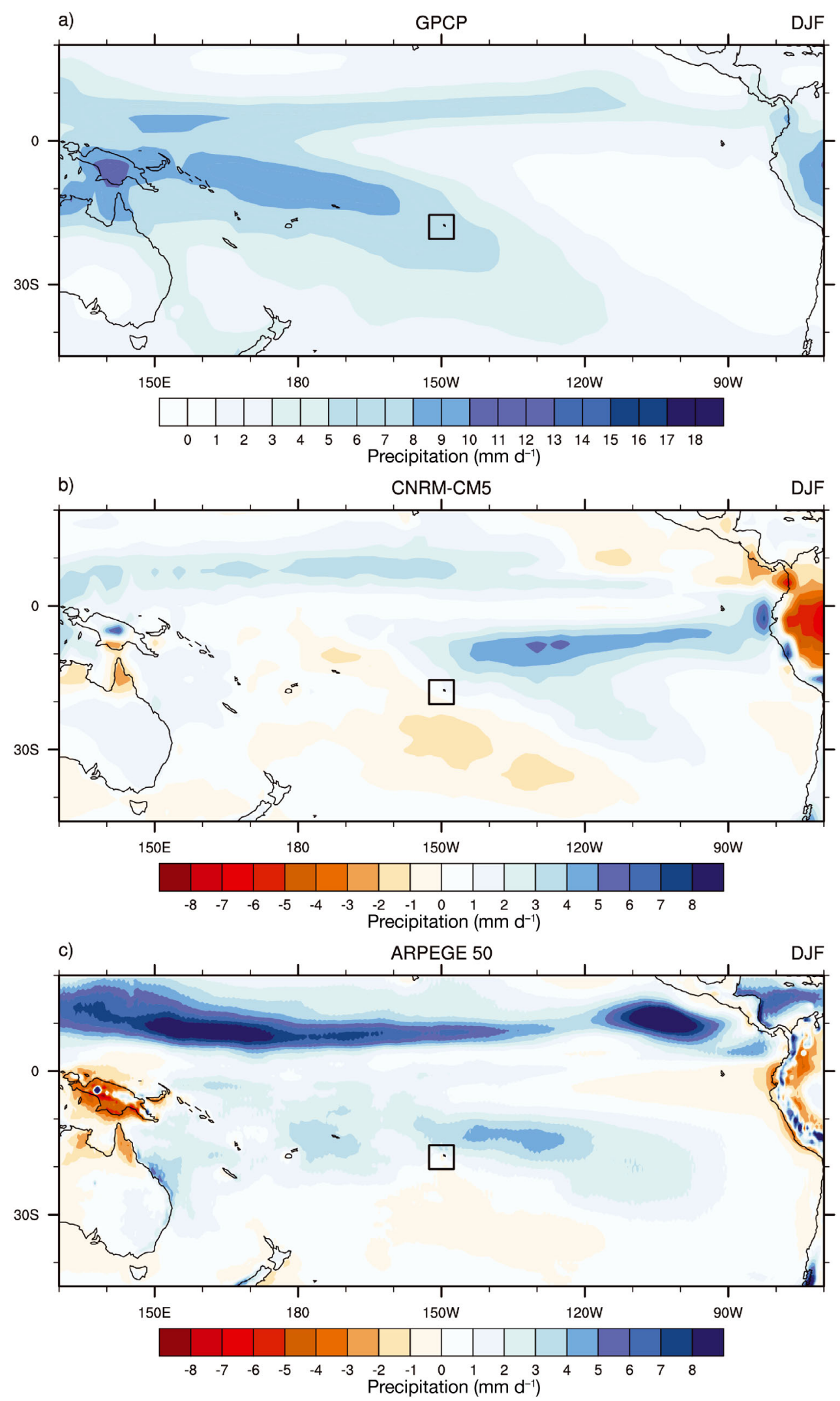

Fig. 3. (a) GPCP austral summer (DJF) mean precipitation rate for the period 1979 to 2010. (b) CNRM-CM5 austral summer (DJF) mean precipitation for the period 1951 to 2005. (c) ARPEGE $50 \mathrm{~km}$ austral summer (DJF) mean precipitation for the period 1951 to 2005 
observations and model results is made over the historical period.

A major comment concerns the historical forcing: the SST used does not refer to observational gridded datasets but is from the CNRM-CM historical SST fields, and consequently, no common chronology is possible between observed and modelled variables (e.g. the El Niño events occur in different years). This linkage, based on a long learning period, is assumed to remain valid over the 21st century; details on the assumptions made are presented in Subsection 4.2.

\subsection{Relevant grid cell selection using the ENSO response}

A lack of common chronology implies a lack of correlation between model and observations. In addition, to reduce the RCM output to only relevant grid cells, the impact of ENSO is investigated over both observed and RCM precipitation.

Fig. 4 shows warm (El Niño) and cold (La Niña) ENSO observed precipitation composites (December, January and February months only) over the period 1961 to 2011.

The El Niño (La Niña) composite consists of the average of precipitation anomalies over El Niño (La Niña) dates. El Niño dates are selected according to the Niño3.4 index values. Typically, from 1961 to 2011, months for which the Niño3.4 index is $>0.5$ are defined as El Niño months (28 of 96). La Niña months correspond to Niño3.4 values <-0.5 (30 of 96).

During warm events, windward stations get wetter while leeward stations are shielded by the orography. Hopuare et al. (2015) proposed that this orographic pattern results from the combined effects of the positive phase of IPO and El Niño on the position of the SPCZ. Displaced equatorward, the SPCZ and the associated low-pressure zone modify the trajectory of the southeast trade winds, causing a northward flow responsible for the orographic precipitation at the southernmost stations. Cold events seem to favour an overall drying of the stations. Hopuare et al. (2015) argued that this signal is possibly generated by the SPCZ northwestward contraction in the western part of the basin, which deprives the island of convective precipitation. Consequently, a substantial and robust contrast of precipitation amount is seen at the southern windward stations (Papara5, Papeari1, Afaahiti3, Afaahiti4 and Teahupoo1) depending on the phase of ENSO. Since no clear relationship can be established between northern leeward stations and ENSO, these stations are not

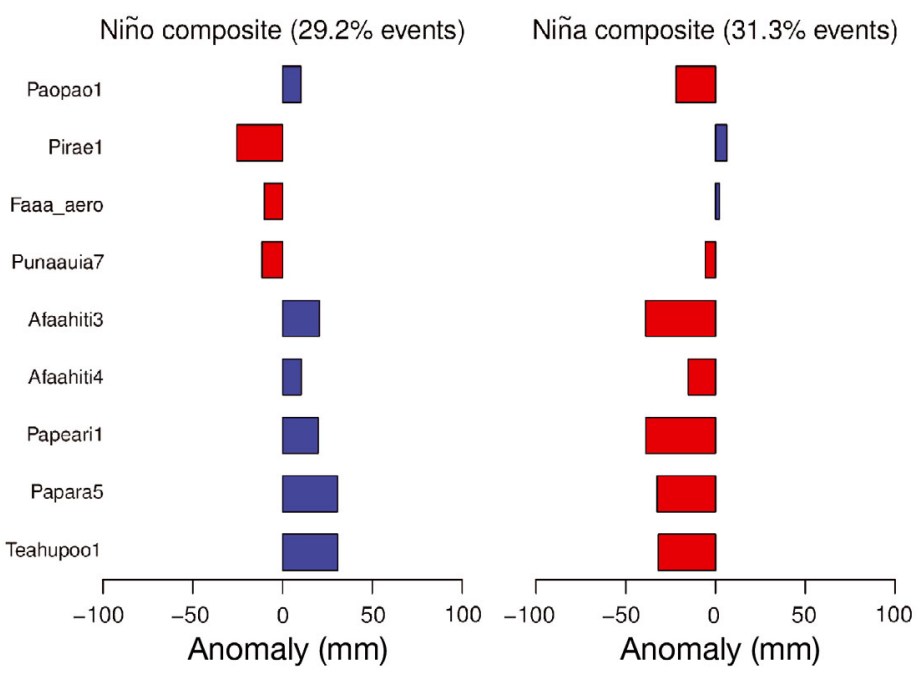

Fig. 4. Composite Niño: precipitation anomalies at stations averaged over El Niño events of the period 1961 to 2011. Composite Niña: precipitation anomalies at stations averaged over La Niña events of the period 1961 to 2011

further considered here. The results are presented for Papara5 and Teahupoo1 because they show the most robust ENSO-related precipitation signal.

In order to characterize the modelled warm and cold ENSO events generated by the RCM, the following procedure has been applied:

(1) A 'model' Niño3.4 index is built following the procedure used to calculate the Niño3.4 index. The monthly SST anomalies used to force ARPEGE $50 \mathrm{~km}$ are spatially averaged over the Niño3.4 box $\left(170^{\circ}\right.$ to $120^{\circ} \mathrm{W} ; 5^{\circ} \mathrm{S}$ to $5^{\circ} \mathrm{N}$ ). These anomalies refer to the differences with respect to the SST monthly climatology based on the historical period 1951 to 2005 .

(2) Months within warm and cold events are selected according to the 'model' Niño3.4 index values. El Niño months correspond to 'model' Niño3.4 index $>0.5$; La Niña months correspond to 'model' Niño3.4 index $<-0.5$. This threshold allows us to consider not only strong ENSO events but also weak and moderate events. Modelled interannual variability is in agreement with observations as shown by the statistics of Niño3.4 in Fig. 5, derived from the reference SST dataset and the corrected SSTs from CNRM-CM5.

(3) The model warm and cold ENSO precipitation composites were computed for the historical run following the methodology employed with the observations. The results are presented in Fig. 6 .

A consistent behaviour, similar to that of the southern stations, can be seen for a few 'sea' grid cells located to the south-east of the island. Warm (cold) events imply positive (negative) precipitation anomalies. This spurious position of the ENSO-related pre- 


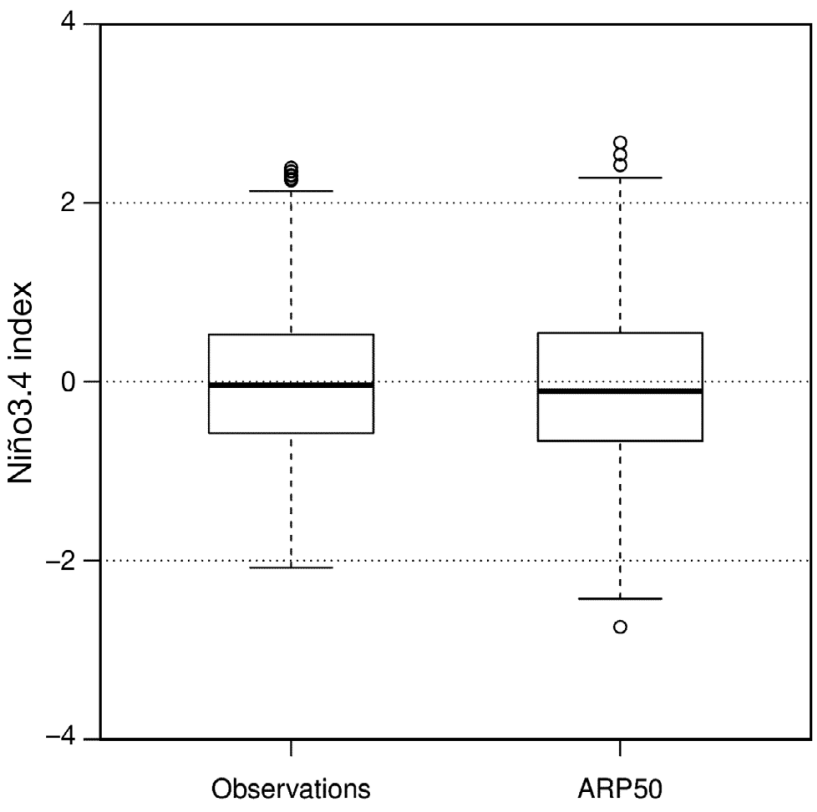

Fig. 5. Observed and modeled Niño3.4 index boxplots. The box extends from the first to third quartile. The median is represented by a thick black line within the box. Whiskers extend up to the value that equals 1.5 times the interquartile range. Outliers are displayed as little black circles. Black dotted lines have been added to $\mathrm{y}=-2, \mathrm{y}=0$ and $\mathrm{y}=2$ to assist the viewer. Observed Niño3.4 monthly values come from NOAA (www.cpc.ncep.noaa.gov/data/indices/). ARPEGE $50 \mathrm{~km}$ monthly SSTs, over the period 1951-2005, were used to compute the modeled Niño3.4 index

cipitation signal could result from the combined effect of various biases such as insufficient resolution of the orography, hydrostatic approximation and deep convection parameterization.

Even though orographic precipitation signal is misplaced over the sea, the modelling tools and downscaling method show the ability to capture a signal linked to the island's orography. In order to establish a robust relationship between model and observation, the most contrasted grid-point, i.e. the one that shows the greatest difference from El Niño to La Niña composites, is chosen as the grid cell of interest.

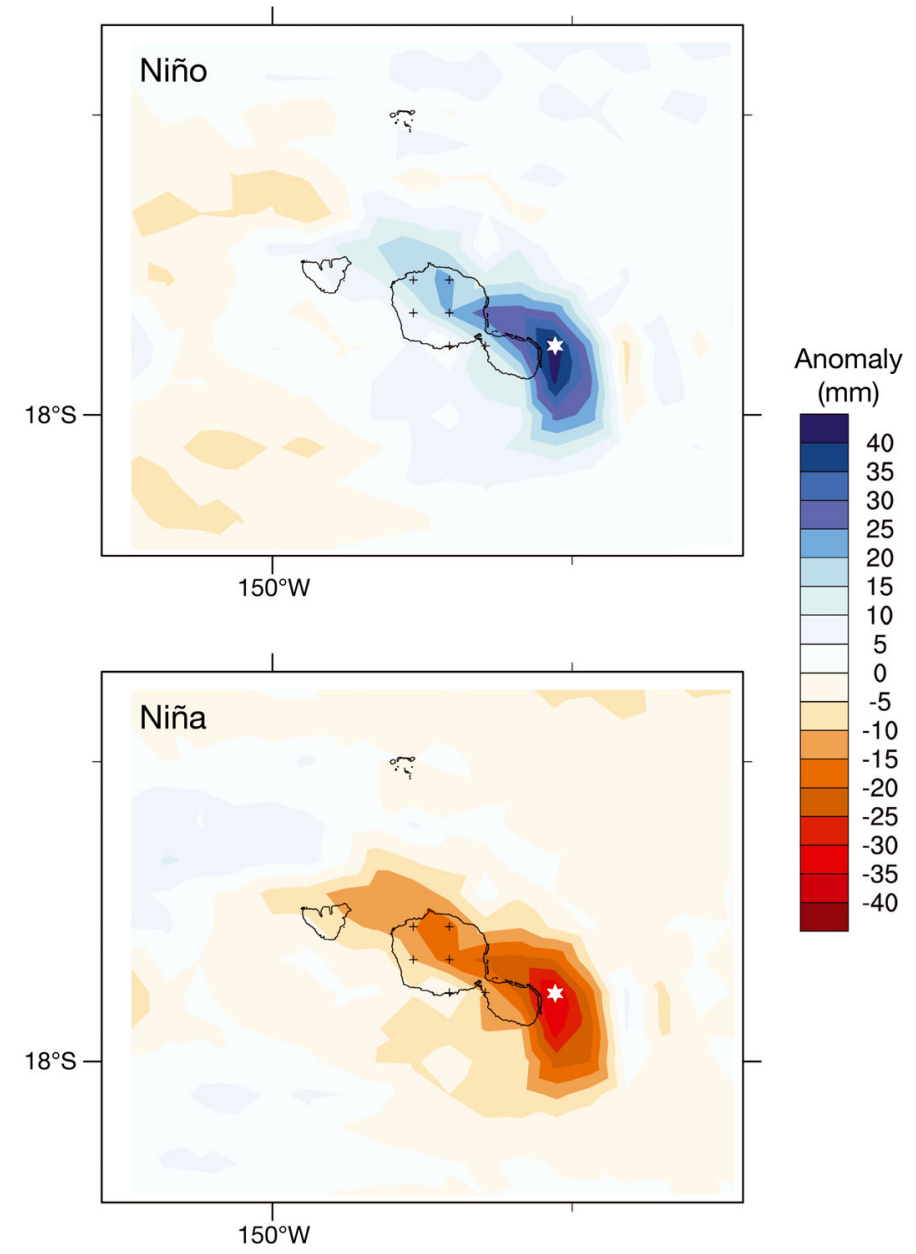

Fig. 6. Composite Niño: modelled precipitation anomalies of ALADIN Tahiti averaged over modelled El Niño events of the historical period (from ARPEGE $50 \mathrm{~km}$ ). Composite Niña: modelled precipitation anomalies of ALADIN Tahiti averaged over modelled La Niña events of the historical period (from ARPEGE $50 \mathrm{~km}$ ). Black crosses are plotted on the land grid points of the island, as resolved by ALADIN. A white asterisk indicates the sea grid point of interest

Table 1 displays the root mean square error of DJF precipitation amounts; the reference dataset corresponds to the 9 stations, and the selected RCM grid

Table 1. Root mean square error of DJF precipitation amounts in RCM 6 land grid cells and 1 sea grid cell, south-east of the land grid cells (in mm)

\begin{tabular}{|c|c|c|c|c|c|c|c|c|c|}
\hline Grid point & Teahupoo1 & Papara5 & Papeari1 & Afaahiti4 & Afaahiti3 & Punaauia 7 & Faaa_aero & Pirae1 & Раорао1 \\
\hline Sea & 438.2 & 213.7 & 485.8 & 755.5 & 768.5 & 257.1 & 182.0 & 532.4 & 496.2 \\
\hline Land 1 & 310.0 & 85.6 & 357.7 & 627.4 & 640.4 & 128.9 & 53.9 & 404.3 & 368.1 \\
\hline Land 2 & 457.8 & 233.3 & 505.4 & 775.1 & 788.1 & 276.7 & 201.6 & 552.0 & 515.9 \\
\hline Land 3 & 551.4 & 327.0 & 599.1 & 868.8 & 881.8 & 370.3 & 295.3 & 645.7 & 609.5 \\
\hline Land 4 & 681.4 & 456.9 & 729.1 & 998.7 & 1011.7 & 500.3 & 425.3 & 775.6 & 739.5 \\
\hline Land 5 & 541.7 & 317.3 & 589.4 & 859.1 & 872.1 & 360.6 & 285.6 & 635.9 & 599.8 \\
\hline Land 6 & 632.2 & 407.8 & 679.9 & 949.5 & 962.6 & 451.1 & 376.1 & 726.4 & 690.3 \\
\hline
\end{tabular}


cells include the 6 land points and the sea point upstream to the land points. The RCM tends to underestimate observed amounts (an average bias of $\sim 200 \mathrm{~mm}$ ). Probability distribution functions (PDFs) of modelled and observed DJF precipitation amounts are displayed in Fig. 7. The discrepancy between RCM and observed values appears through the PDF plots: RCM simulates a great number of moderately wet austral summers, whereas the stations show a more flat distribution centred on higher values of precipitation.

\subsection{Statistical adjustment method}

The statistical relationship between stations and grid cell was identified using Q-Q plots (Fig. 8) and adapting statistical transformations to adjust RCM DJF total precipitation to the station scale. A comparison of methods is provided by Gudmundsson et al. (2012). These Q-Q plots bring together DJF precipitation anomalies (with respect to the corresponding climatology) from station data and model grid cells, as proposed by Déqué (2007). The apparent linear relationship between model grid cells and each station has been fitted using linear regression:

$$
\Delta \operatorname{RRobs}^{i}=\mathrm{A}^{i} \cdot \Delta \mathrm{RRmod}+\mathrm{B}^{i}
$$

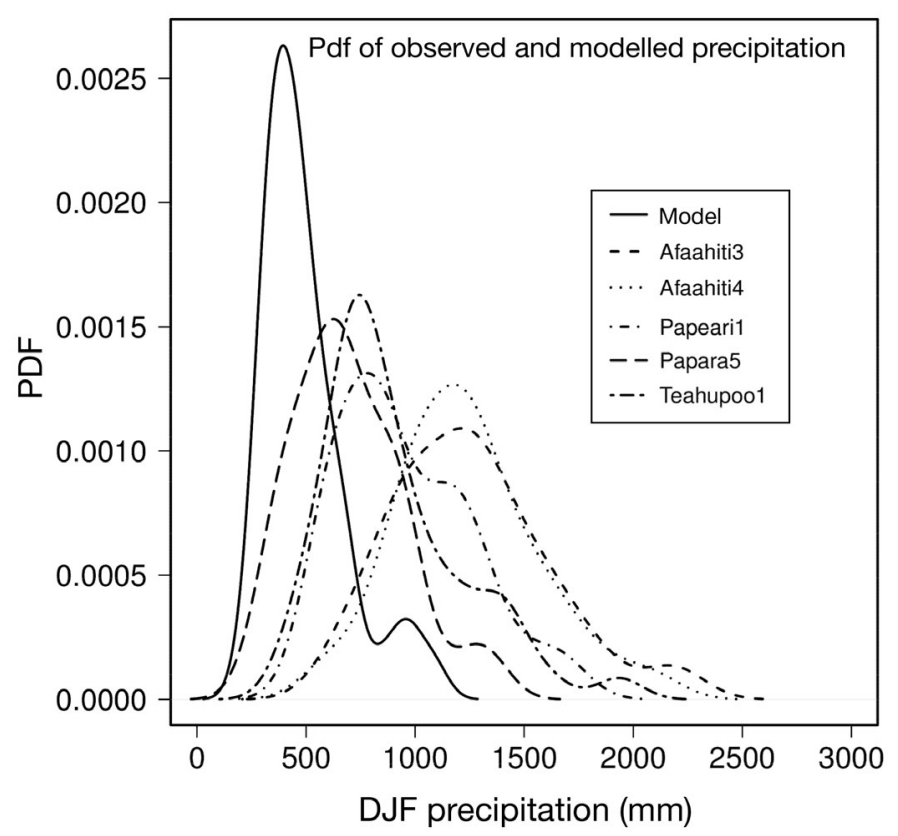

Fig. 7. PDF of DJF precipitation amounts for the RCM sea grid point of interest and the windward stations of Afaahiti3, Afaahiti4, Papeari1, Papara5 and Teahupoo1. The figure key shows the type of line that has been attributed to the RCM grid point and to each station where $\Delta$ RRobs is the DJF precipitation anomaly at the $i^{\text {th }}$ station, $\Delta$ RRmod is the DJF precipitation anomaly at the selected grid point of the RCM, and A and $\mathrm{B}$ are the coefficients from the linear regression obtained for the $i^{\text {th }}$ station.

Over the historical period, Eq. (1) expresses a linear relationship between DJF station precipitation anomaly (departure from the observed climatology) and DJF model grid cell precipitation anomaly (departure from the model climatology).

Fig. 8 shows that linear regression successfully represents the relationship between the grid cell DJF anomalies and the other stations' DJF anomalies. Not surprisingly, the main bias of the model resides in the underestimation of extreme precipitation events. The lowestand highest quantiles areindeedless well-fitted.

However, a few assumptions should be made prior to using the statistical relationship established:

(1) It is assumed that the precipitation anomalies are mainly caused by interannual variability through ENSO events. As seen in Subsection 4.1, El Niño events bring positive precipitation anomalies, while La Niña events cause negative precipitation anomalies onto the southernmost stations. This hypothesis seems quite reasonable considering the seasonal means of DJF months.

(2) The statistical linkage established between observed and modelled anomalies remains valid in the future. For example, it is assumed that for the 20382069 period, the averages of El Niño DJF precipitation anomalies are derived from the corresponding average of model El Niño DJF 2038-2069 precipitation anomalies (with respect to the 2038-2069 climatology).

(3) This relationship is used to describe the changes in the mean state along the 21st century (with respect to the historical mean state) due to GHG-induced climate change. It is assumed that, at large scale, the spatial structure of the Pacific SSTs is trending towards an El Niño-like pattern. The ARPEGE $50 \mathrm{~km}$ SST trends in the Pacific along the 21st century confirm this assumption. Moreover, the conclusions from the IPCC's last report (Stocker et al. 2013) indicate that this hypothesis is somewhat reasonable. The equatorial warming of the Pacific is projected to increase, and is consistent with the projected weakening of the Pacific Walker cell.

Considering 3 scenario periods 2006-2037, 20382069 and 2070-2100, Eq. (1) could be used to derive the supposed DJF changes in the real world ( $30 \mathrm{yr}$ average) with respect to the historical mean. In this case, the model anomalies in Eq. (1) correspond to $30 \mathrm{yr}$ mean departures from the historical mean. 

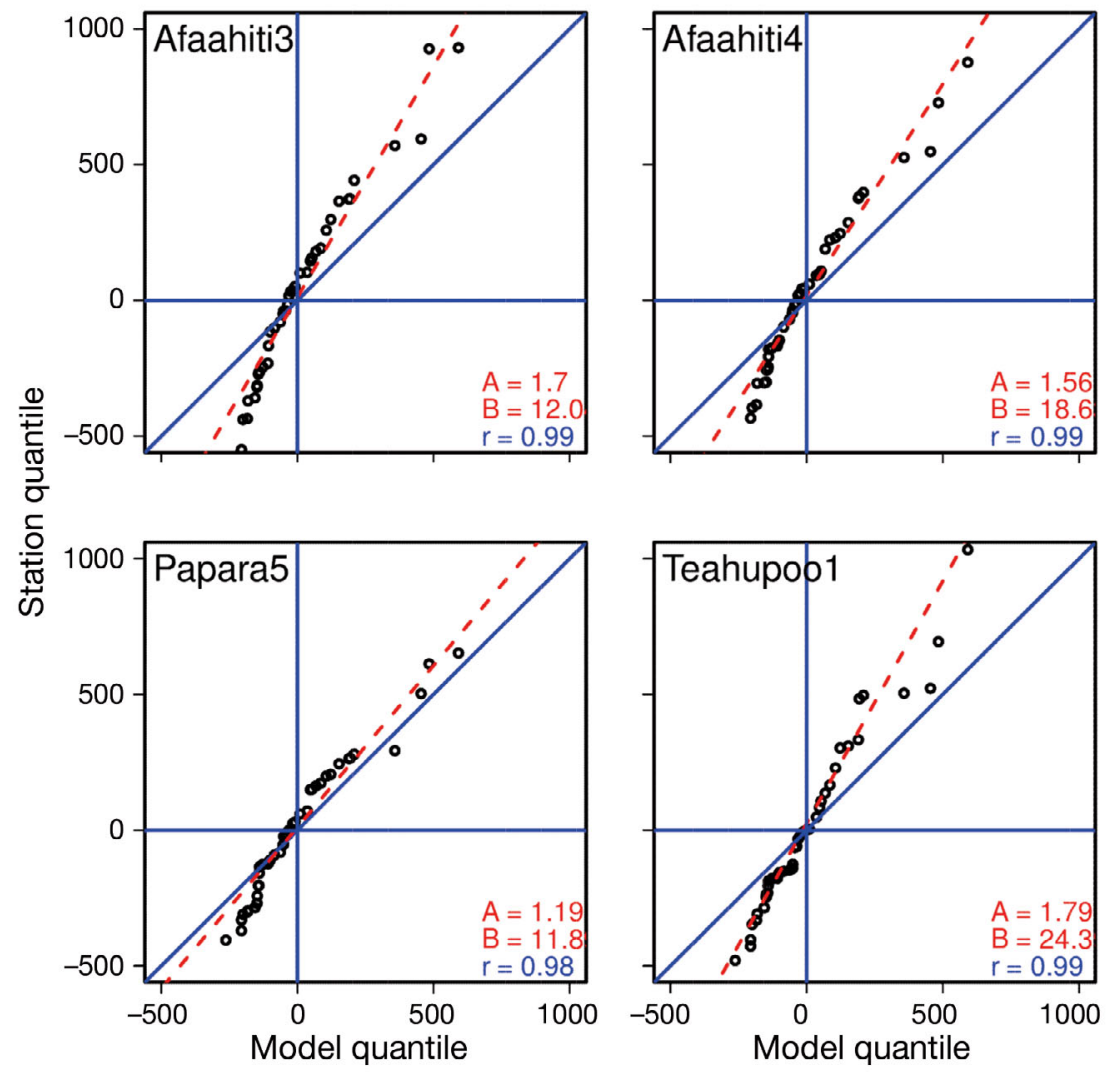

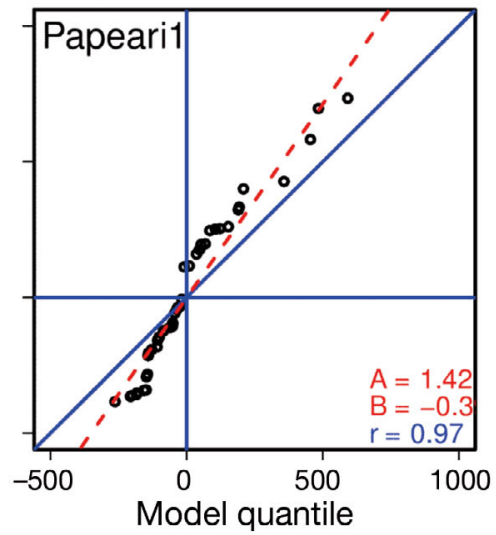

Fig. 8. Q-Q plots of observed precipitation DJF anomalies from each windward station against the modelled precipitation DJF anomalies from the grid cell exhibiting the maximum contrast between model El Niño and La Niña. The best linear fit is represented by a dashed red line. The slope and intercept of the regression line correspond to coefficients $\mathrm{A}$ and $\mathrm{B}$, respectively. $\mathrm{r}$ denotes the Pearson correlation coefficient. Blue lines have been added to $x=0, y=0$, and $y=x$ to assist the viewer

\section{FUTURE PRECIPITATION CHANGES IN TAHITI ACCORDING TO RCP4.5 AND RCP8.5}

The future changes in Tahiti's precipitation are derived from future model changes thanks to available downscaled RCP4.5 and RCP8.5 scenario runs and observation-based adaptation and RCM precipitation correction.

The evolution of DJF mean precipitation during the 21st century (with respect to the 20th century mean) in response to greenhouse gas-induced climate change is assessed for three $30 \mathrm{yr}$ periods using the model grid cell of interest (defined in Subsection 4.1). Basically, for this grid cell, the DJF precipitation amounts are averaged for the historical period and for each scenario time slice. As an example, the mean change of precipitation for the RCP8.5 over the 20062037 time slice is taken as the difference between the mean precipitation amount for the RCP8.5 over 2006-2037 and the mean precipitation amount for the historical period. Then, DJF precipitation anomalies due to ENSO events are computed. El Niño and La Niña events are determined according to the 'model' Niño3.4 index values. Following the same example, El Niño (La Niña) precipitation anomalies for the RCP8.5 during 2006-2037 are computed as the difference between the precipitation amount averaged over all the El Niño (La Niña) events of the period and the mean precipitation amount for the same period (i.e. RCP8.5 2006-2037 climatology).

Fig. 9 shows model grid-point and inferred DJF precipitation amounts for the 2 southernmost stations during the 21st century: Teahupoo1 and Papara5. These 2 stations indeed show the most robust ENSOrelated signal. The historical mean DJF amounts are represented by black bars; the light grey bars and dark grey bars correspond respectively to RCP4.5 and RCP8.5 mean DJF amounts. The adjacent blue and red bars represent the average amount of precipitation occurring respectively during El Niño and La Niña events (these events being inferred from the CNRM-CM simulations).

The model precipitation changes of the mean state along the 21st century are positive for both RCP4.5 and RCP8.5 scenarios and keep increasing with time. Interestingly, the 2 scenarios exhibit fairly similar long-range positive precipitation changes. RCP4.5 changes appear slightly greater than RCP8.5, but this 


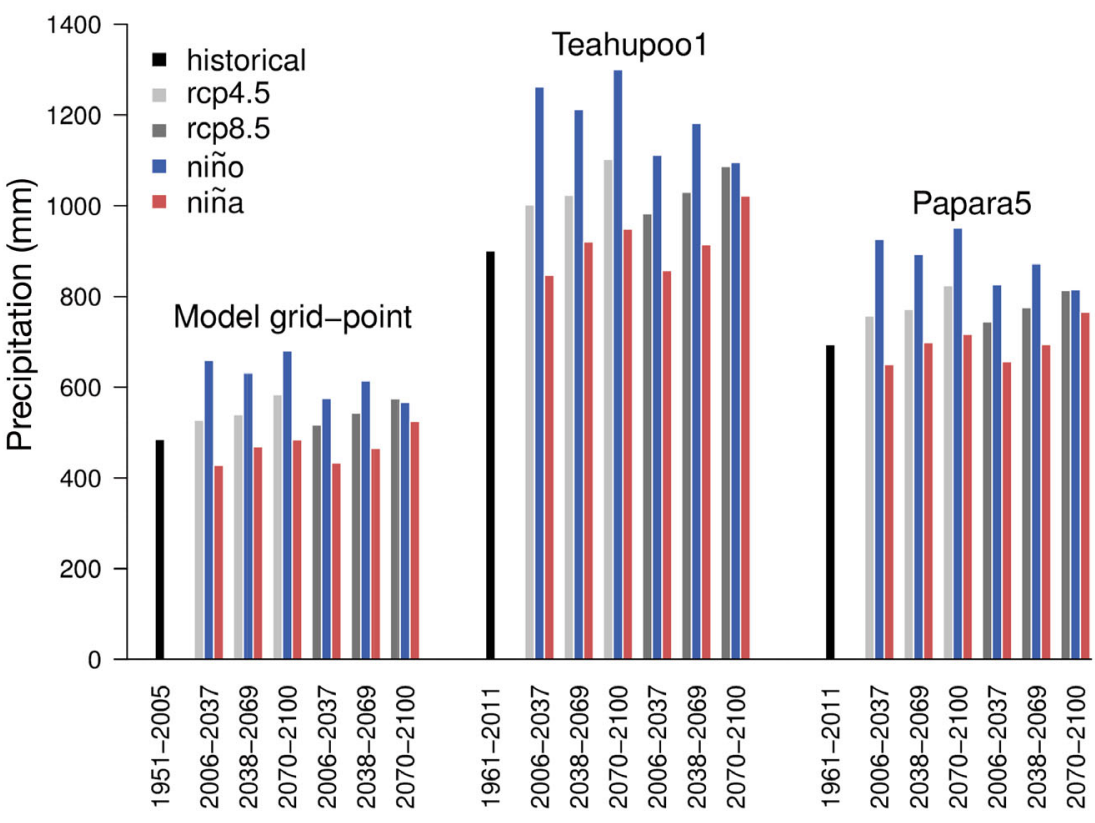

Fig. 9. The most ENSO-contrasted model grid point mean precipitation amounts for: historical (black; 1951-2005), RCP4.5 (light grey; 2006-2037, 2038-2069 and 2070-2100), and RCP8.5 (dark grey; 2006-2037, 2038-2069 and 20702100), as well as mean precipitation amounts averaged over modelled El Niño (blue) and La Niña (red). Warm and cold ENSO months are selected according to the model Niño3.4 index values. El Niño months correspond to SSTs from ARPEGE $50 \mathrm{~km}$ Niño3.4 index >0.5; La Niña months correspond to Niño3.4 index $<-0.5$. Identical precipitation amounts have been calculated for Teahupoo1 and Papara5 stations using the linear relationship between each station and the model grid point, derived from Q-Q plots
The mean change in precipitation and corresponding ENSO anomalies at each station are derived using Eq. (1), and Q-Q plot adjustment allows an assessment of future precipitation for stations in Tahiti.

For example, Teahupoo1 station (see Table 2), registers, on average, $122.7 \mathrm{~mm}$ of excess precipitation (with respect to the 1961-2011 DJF mean amount: $901.4 \mathrm{~mm}$ ), hence an increase of about $13.6 \%$ in the case of the RCP4.5 range of 2038-2069. During this period, El Niño events cause additional positive precipitation anomalies. The mean anomaly for the El Niño events of 2038-2069 reaches $188.8 \mathrm{~mm}$, that is to say an increase of about $+18.4 \%$ with respect to the 2038-2069 RCP4.5 climatology. Conversely, La Niña events imply negative precipitation anomalies. The mean anomaly for the La Niña events of 2038 to 2069 reaches $-102.7 \mathrm{~mm}$, in other words, a decrease of about $-10 \%$ with respect to the 2038-2069 RCP4.5 climatology. For Teahupoo1 and Papara5 station, the values are summarized in Table 2 for each scenario and time slice.

feature was insignificant according to Wilcoxon's test. However, one would expect the positive precipitation changes to be significantly greater in the case of scenario RCP8.5, following thermodynamics. It is probable that the dynamic response to global warming, i.e. the weakening of the tropical circulation, plays a role in balancing the thermodynamic response.

Superimposed on each time slice climatology, El Niño (La Niña) events cause an increase (decrease) in precipitation. The amplitude of El Niño anomalies is significantly greater than that of La Niña (Wilcoxon's statistics) in both scenarios but becomes insignificant for the last period of the RCP8.5.

For the last $30 \mathrm{yr}$ of RCP8.5, the model El Niño and La Niña precipitation anomalies appear diminished. Under the RCP8.5 scenario, the 2070-2100 El Niño events imply a slight decrease in precipitation instead of the usual increase. The 2070-2100 La Niña events cause a smaller decrease in precipitation compared to La Niña events of earlier RCP8.5 periods. This behaviour suggests the impact of ENSO on precipitation (especially El Niño) gets weaker during the 21st century for the RCP8.5.
In the particular case of RCP8.5 2070-2100, the wet season in Teahupoo1 registers on average $185.8 \mathrm{~mm}$ of excess precipitation (20.6\% increase) due to GHG warming, only $9.3 \mathrm{~mm}$ more during El Niño events ( $1 \%$ increase) and $64.8 \mathrm{~mm}$ less ( 6\% decrease) during La Niña events. In the case of Papara5 (Table 2 ), the wet season receives, on average, $119.2 \mathrm{~mm}$ of excess precipitation (17.2\% increase) due to GHG warming, only $1.9 \mathrm{~mm}$ more ( $0.2 \%$ increase) during El Niño events and $47.4 \mathrm{~mm}$ less (5.8\% decrease) during La Niña events. The El Niño precipitation anomalies for the period 2070 to 2100 are significantly reduced compared to anomalies of 2006-2037 and 2038-2069. In the La Niña case, the results are not significant.

To sum up, austral summer precipitation increases in model projections at windward stations along the 21st century. The regular increase in precipitation during the century is assumed to be the consequence of GHG warming, whereas interannual variability implies further increases in the case of El Niño or decreases in the case of La Niña. These primary results suggest that future water resources would not be crit- 
Table 2. Teahupoo1 and Papara5 changes in precipitation (statistically significant values in bold) with respect to historical mean and changes in precipitation due to El Niño and La Niña events with respect to the corresponding climatology

\begin{tabular}{|c|c|c|c|c|c|c|}
\hline & \multicolumn{2}{|c|}{ Mean state } & \multicolumn{2}{|c|}{ Niño } & \multicolumn{2}{|c|}{ Niña } \\
\hline & $(\mathrm{mm})$ & $(\%)$ & $(\mathrm{mm})$ & $(\%)$ & $(\mathrm{mm})$ & $(\%)$ \\
\hline \multicolumn{7}{|l|}{ Teahupoo1 } \\
\hline \multicolumn{7}{|l|}{ 2006-2037 } \\
\hline RCP $4.5 x$ & 101.3 & 11.20 & 260 & 25.90 & -155.2 & -15.50 \\
\hline RCP8.5 & 81.7 & 9.10 & 129.5 & 13.20 & -125.5 & -12.80 \\
\hline \multicolumn{7}{|l|}{ 2038-2069 } \\
\hline RCP $4.5 x$ & 122.7 & 13.60 & 188.8 & 18.40 & -102.7 & -10.00 \\
\hline RCP8.5 & 128.9 & 14.30 & 152.3 & 14.80 & -115.4 & -11.20 \\
\hline \multicolumn{7}{|l|}{$2070-2100$} \\
\hline RCP4.5x & 201.3 & 22.30 & 198.2 & 18.00 & -153.5 & -13.90 \\
\hline RCP8.5 & 185.8 & 20.60 & 9.3 & 0.90 & -64.8 & -6 \\
\hline \multicolumn{7}{|l|}{ Papara5 } \\
\hline \multicolumn{7}{|l|}{$2006-2037$} \\
\hline $\mathrm{RCP} 4.5$ & 63 & 9.10 & 168.5 & 22.20 & -107.5 & -14.20 \\
\hline RCP8.5 & 50 & 7.20 & 81.8 & 11.00 & -87.8 & -11.80 \\
\hline \multicolumn{7}{|l|}{$2038-2069$} \\
\hline RCP4.5 & 77.2 & 11.10 & 121.2 & 15.70 & -72.6 & -9.40 \\
\hline RCP8.5 & 81.4 & 11.70 & 96.9 & 12.50 & -81 & -10.40 \\
\hline \multicolumn{7}{|l|}{$2070-2100$} \\
\hline $\mathrm{RCP} 4.5$ & 129.5 & 18.60 & 127.4 & 15.50 & -106.4 & -12.90 \\
\hline RCP8.5 & 119.2 & 17.20 & 1.9 & 0.20 & -47.4 & -5.80 \\
\hline
\end{tabular}

porally averaged over three $10 \mathrm{yr}$ periods of the 21st century: 20102020, 2050-2060 and 2090-2100. The difference between the boxes is used to assess the zonal SST gradient. Along the 21st century, the zonal contrast of SST in ARPEGE $50 \mathrm{~km}$ actually decreases: from $4.06^{\circ} \mathrm{C}$ in 2010 to 2020 , dropping to $3.80^{\circ} \mathrm{C}$ in 2090 to 2100 .

\section{SUMMARY AND CONCLUSIONS}

The present study proposes an island downscaling over a South Pacific French territory: Tahiti. Its main goal is to test an approach usable by other modelling groups to assess climate change impacts at the island-scale. This method could be applied to other Pacific islands not covered by any CORDEX domains. The use of at least 2 successive dynamical downscalings have been necessary to coarsely resolve the island of Tahiti $\left(\sim 30 \times 30 \mathrm{~km}^{2}\right)$ up to 6 land grid cells. The corrected and interpolated SST fields from the

ical for the windward coasts of Tahiti. In the case of RCP8.5 at the end of the century, the increase in wet season precipitation seems to be dominated by GHG warming, while the effects of El Niño have substantially diminished. During the 21st century, the Pacific Ocean surface slowly drifts towards an El Niño-like spatial structure. This feature is confirmed in Fig. 10, which displays the SST trend of ARPEGE $50 \mathrm{~km}$ for scenario RCP4.5 and RCP8.5. The Eastern equatorial Pacific SSTs seem to rise more sharply than in the western part of the basin. The drift would become such that, at the end of the century, the SST contrast between the western warm pool and the eastern equatorial cold tongue would be reduced. As the zonal SST gradient is smoothed, future El Niño SST anomalies would cause weaker atmospheric responses as well, which could explain the reduced effect on precipitation. To assess the decrease in the SST gradient, we chose 2 boxes along the equatorial Pacific: the first one located in the western part of the basin, $160^{\circ}$ to $170^{\circ} \mathrm{E}, 5^{\circ} \mathrm{N}$ to $5^{\circ} \mathrm{S}$, and the other in the Eastern Pacific, $90^{\circ}$ to $80^{\circ} \mathrm{W}, 5^{\circ} \mathrm{N}$ to $5^{\circ} \mathrm{S}$. The values of SST are spatially averaged over each box and tem-
CNRM-CM historical, RCP4.5 and RCP8.5 runs were used to produce the first downscaling with a global $50 \mathrm{~km}$ atmospheric simulation (ARPEGE $50 \mathrm{~km}$ ). The preliminary SST bias-correction step has slightly improved the South Pacific Convergence Zone position in austral summer, but no progress has been achieved for austral winter. The SPCZ position, which marks out a convective precipitation area and hence determines water supply, is crucial for small island territories scattered over the Pacific Ocean. However, global coupled models participating in the IPCC's 5th assessment report struggle to adequately simulate the SPCZ features (Brown et al. 2013). Future improvements are expected in the forthcoming CMIP experiments regarding the representation of the SPCZ.

ARPEGE $50 \mathrm{~km}$ has then been used to drive the limited area model ALADIN $12 \mathrm{~km}$, which constitutes the 2nd downscaling step. The $12 \mathrm{~km}$ regional simulations provide historical, RCP4.5 and RCP8.5 runs up to 2100. The RCM holds various biases inherited from the ARPEGE $50 \mathrm{~km}$ and CNRM-CM models, such as the SPCZ spurious location. However, it also 


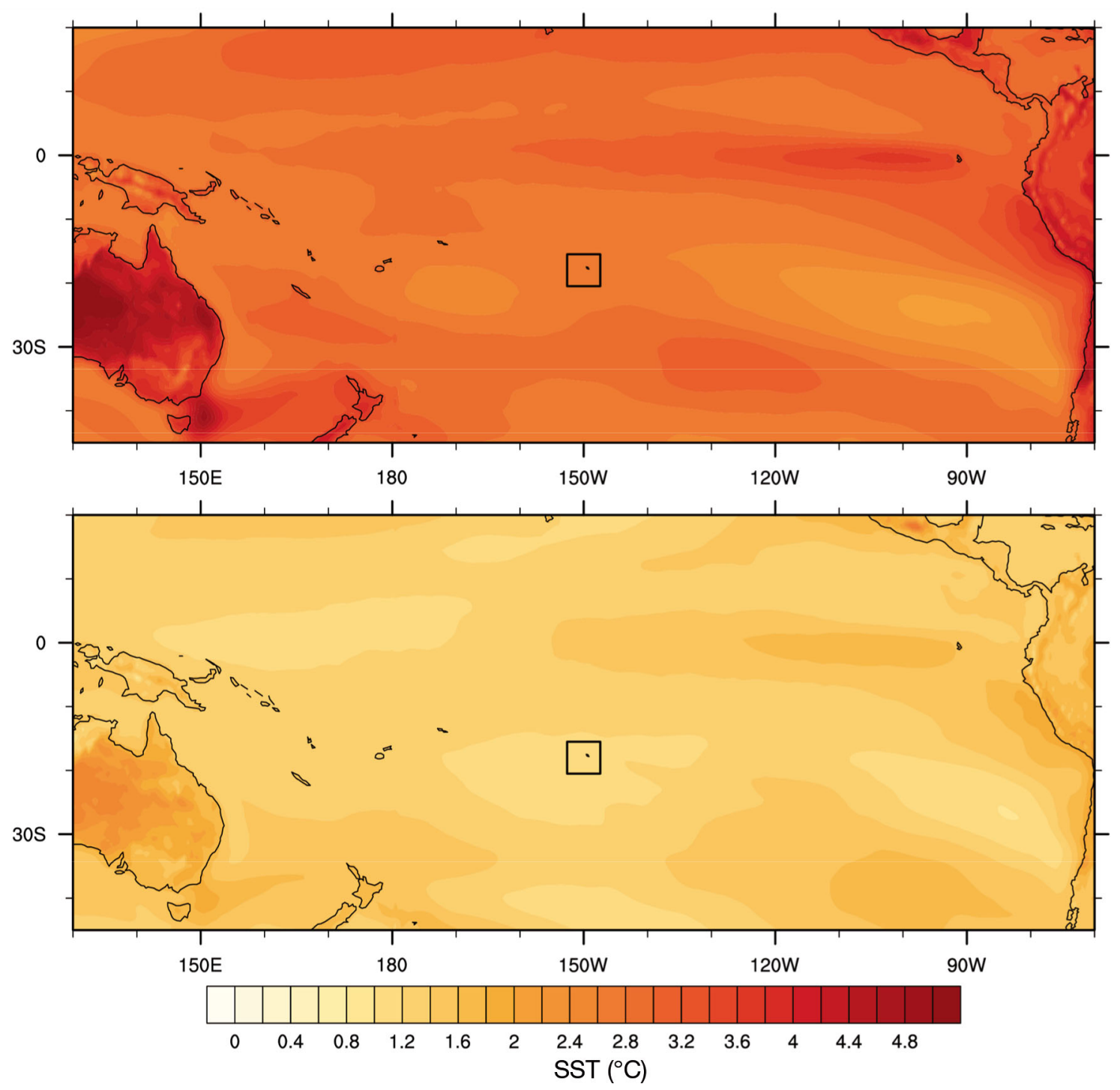

Fig. 10. Trends of ARPEGE $50 \mathrm{~km}$ sea surface temperature (SST) over the period 2005-2100 for RCP8.5 (top panel) and RCP4.5 (bottom panel)

has intrinsic biases due, for example, to a hydrostatic equilibrium assumption that seems inappropriate when considering an island with steep topography at high resolution. The robust ENSO-related orographic precipitation signal is mislocated over the sea, further south-east from the land grid cells. Improvements could be achieved by using a higherresolution non-hydrostatic model, which would be able to displace this signal over better resolved orography. However, the huge computing resources implied could not be envisaged in the next few years for century-long scenario runs.

Nevertheless, the relevant values of this 'sea' grid cell have been used to build a statistical linkage between the regional model and station data. The statistical relationship computed over the historical period is based on quantile-quantile adjustment. This technique was chosen because the historical SSTs from the CNRM-CM did not refer to observed SSTs (AMIP type experiment); hence, no chronology could be made between RCM and station precipitation data. The Q-Q plots reveal the deficiency of the RCM to simulate extreme precipitation. Therefore, a coarse precipitation correction linking observed and modelled precipitation anomaly quantiles is applied. The relationship between observations and RCM is assumed to remain valid over the 21st century, and allows inference of future station precipitation changes.

As only 1 host global model is used for downscaling in this paper, the changes announced here are only a first insight of what the evolution of precipitation 
might be along the 21st century for 2 scenarios (RCP4.5 and RCP8.5). A multi-model approach is necessary to legitimize the results of our study. A possible improvement to make in linking grid cells and local stations would be to use the AMIP experiment that guarantees a common chronology with the stations. This would allow a more confident SST biascorrection method.

The conclusions derived from this study indicate that, following the proposed methodology and the chosen scenarios, the southern stations of Tahiti would likely become wetter than they were in the second half of the 20th century. Additionally, future El Niño (La Niña) events would cause positive (negative) anomalies with respect to the future climatology. In the last $30 \mathrm{yr}$ of the RCP8.5 scenario, future El Niño and La Niña events induce very weak precipitation anomalies, suggesting the impact of ENSO is greatly reduced. A possible explanation for this feature would be that the East-West equatorial Pacific contrast is reduced in the case of RCP8.5, which has been established in SSTs from ARPEGE $50 \mathrm{~km}$. This change implies that future El Niño would not cause substantial departures from the mean state. It should be noted at this point that no conclusion could be derived for the northern stations because they did not show a robust link to ENSO events. This work also reveals that the spatial resolutions used in the CORDEX experiment are currently unsuitable for climate change impact studies over small orographic islands such as Tahiti. Downscaling at $12 \mathrm{~km}$ over Tahiti was insufficient; improvements could be made by using meso-scale Non Hydrostatic models to reach $2 \mathrm{~km}$ resolution. As it represents major computational costs, this additional downscaling should be restrained to specific present or future case studies. Besides these very high-resolution aspects, a credible evaluation of climate change on Pacific islands such as Tahiti would involve the improvement of the SPCZ representation in the next generation of global models (CMIP6).

Acknowledgements. The authors thank the Meteorological Service of French Polynesia (DIRPF - CER Etude) for performing the homogenization procedure on Tahiti's precipitation records and making the data available.

\section{LITERATURE CITED}

Ashfaq M, Bowling LC, Cherkauer K, Pal JS, Diffenbaugh NS (2010) Influence of climate model biases and dailyscale temperature and precipitation events on hydrological impacts assessment: a case study of the United
States. J Geophys Res 115:D14116, doi:10.1029/2009JD 012965

Baigorria GA, Jones JW, Shin DW, Mishra A, O Brien JJ (2007) Assessing uncertainties in crop model simulations using daily bias-corrected Regional Circulation Model outputs. Clim Res 34:211-222

> Becker M, Meyssignac B, Letetrel C, Llovel W, Cazenave A, Delcroix T (2012) Sea level variations at tropical Pacific islands since 1950. Global Planet Change 80-81:85-98

$>$ Bennett JC, Grose MR, Corney SP, White CJ and others (2014) Performance of an empirical bias-correction of a high-resolution climate dataset. Int $\mathrm{J}$ Climatol 34: 2189-2204

Bougeault P (1985) A simple parameterization of the largescale effects of cumulus convection. Mon Weather Rev 113:2108-2121

Brown JR, Moise AF, Colman RA (2013) The South Pacific Convergence Zone in CMIP5 simulations of historical and future climate. Clim Dyn 41:2179-2197

> Bubnová R, Hello G, Bénard P, Geleyn JF (1995) Integration of the fully elastic equations cast in the hydrostatic pressure terrain-following coordinate in the framework of the ARPEGE/ALADIN NWP system. Mon Weather Rev 123: 515-535

> Caussinus H, Mestre O (2004) Detection and correction of artificial shifts in climate series. J R Stat Soc Ser C Appl Stat 53:405-425

> Christensen JH, Boberg F, Christensen OB, Lucas-Picher P (2008) On the need for bias correction of regional climate change projections of temperature and precipitation. Geophys Res Lett 35:L20709, doi:10.1029/2008GL035694

$>$ Dai A (2006) Precipitation characteristics in eighteen coupled climate models. J Clim 19:4605-4630

Davies H (1976) A lateral boundary formulation for multilevel prediction models. QJR Meteorol Soc 102:405-418

Déqué M (2007) Frequency of precipitation and temperature extremes over France in an anthropogenic scenario: model results and statistical correction according to observed values. Global Planet Change 57:16-26

Folland CK, Renwick JA, Salinger MJ, Mullan AB (2002) Relative influences of the Interdecadal Pacific Oscillation and ENSO on the South Pacific Convergence Zone. Geophys Res Lett 29:21-1-21-4

Fowler HJ, Blenkinsop S, Tebaldi C (2007) Linking climate change modelling to impacts studies: recent advances in downscaling techniques for hydrological modelling. Int $\mathrm{J}$ Climatol 27:1547-1578

> Ghosh S, Mujumdar PP (2009) Climate change impact assessment: uncertainty modeling with imprecise probability. J Geophys Res D 114:D18, doi:10.1029/2008JD011648

Gudmundsson L, Bremnes JB, Haugen JE, Engen-Skaugen T (2012) Technical Note: Downscaling RCM precipitation to the station scale using statistical transformations - a comparison of methods. Hydrol Earth Syst Sci 16: 3383-3390

> Hay LE, Clark MP (2003) Use of statistically and dynamically downscaled atmospheric model output for hydrologic simulations in three mountainous basins in the western United States. J Hydrol (Amst) 282:56-75

> Hewitson BC, Crane RG (1996) Climate downscaling: techniques and application. Clim Res 7:85-95

Hopuare M, Pontaud M, Céron JP, Ortéga P, Laurent V (2015) Climate change, Pacific climate drivers and observed precipitation variability in Tahiti, French Polynesia. Clim Res 63:157-170 
Horányi A, Ihász I, Radnóti G (1996) ARPEGE/ALADIN: a numerical weather prediction model for Central-Europe with the participation of the Hungarian Meteorological Service. Idojárás 100:277-301

Leander R, Buishand TA (2007) Resampling of regional climate model output for the simulation of extreme river flows. J Hydrol (Amst) 332:487-496

Lenderink G, Buishand A, van Deursen W (2007) Estimates of future discharges of the river Rhine using two scenario methodologies: direct versus delta approach. Hydrol Earth Syst Sci 11:1145-1159

Lin JL (2007) The double-ITCZ problem in IPCC AR4 coupled GCMs: ocean-atmosphere feedback analysis. J Clim 20:4497-4525

Louis JF (1979) A parametric model of vertical eddy fluxes in the atmosphere. Boundary-Layer Meteorol 17:187-202

Madec G (2008) The NEMO ocean engine, Note du Pôle de Modlisation de L'IPSL. Available at www.nemo-ocean. eu/content/download/15482/73217/file/NEMO_book_ v3_3.pdf

Mantua NJ, Hare SR, Zhang Y, Wallace JM, Francis RC (1997) A Pacific interdecadal climate oscillation with impacts on salmon production. Bull Am Meteorol Soc 78: 1069-1079

Matthews AJ (2012) A multiscale framework for the origin and variability of the South Pacific Convergence Zone. QJR Meteorol Soc 138:1165-1178

Meehl GA, Stocker TF, Collins WD, Friedlingstein P and others (2007) Global climate projections. In: Solomon S, Qin D, Manning M, Chen Z and others (eds) Climate change 2007: the physical science basis. Contribution of Working Group I to the Fourth Assessment Report of the Intergovernmental Panel on Climate Change. Cambridge University Press, New York, NY, p 749-845

Milly PCD, Betancourt J, Falkenmark M, Hirsch RM, Kundzewicz ZW, Lettenmaier DP, Stouffer RJ (2008) Stationarity is dead: whither water management? Science 319:573-574

Morcrette JJ (1990) Impact of changes to the radiation transfer parameterizations plus cloud optical properties in the ECMWF model. Mon Weather Rev 118:847-873

Noilhan J, Mahfouf JF (1996) The ISBA land surface parameterisation scheme. Global Planet Change 13:145-159

Noilhan J, Planton S (1989) A simple parameterization of land surface processes for meteorological models. Mon Weather Rev 117:536-549

Editorial responsibility: Eduardo Zorita, Geesthacht, Germany
Oueslati B, Bellon G (2013) Convective entrainment and large-scale organization of tropical precipitation: sensitivity of the CNRM-CM5 hierarchy of models. J Clim 26: 2931-2946

> Piani C, Haerter JO, Coppola E (2010) Statistical bias correction for daily precipitation in regional climate models over Europe. Theor Appl Climatol 99:187-192

Ricard JL, Royer JF (1993) A statistical cloud scheme for use in an AGCM. Ann Geophys 11:1095-1115

Salas-Mélia D (2002) A global coupled sea ice-ocean model. Ocean Model 4:137-172

- Salinger MJ, McGree S, Beucher F, Power SB, Delage F (2013) A new index for variations in the position of the South Pacific convergence zone 1910/1911-2011/2012. Clim Dyn 43:881-892

Smith RNB (1990) A scheme for predicting layer clouds and their water content in a general circulation model. QJR Meteorol Soc 116:435-460

Stocker TF, Dahe Q, Plattner GK (2013) Climate change 2013: the physical science basis. Working Group I Contribution to the Fifth Assessment Report of the Intergovernmental Panel on Climate Change Summary for Policymakers (IPCC 2013)

Teutschbein C, Seibert J (2010) Regional climate models for hydrological impact studies at the catchment scale: a review of recent modeling strategies. Geogr Compass 4 : 834-860

> Vincent EM, Lengaigne M, Menkes CE, Jourdain NC, Marchesiello P, Madec G (2011) Interannual variability of the South Pacific Convergence Zone and implications for tropical cyclone genesis. Clim Dyn 36:1881-1896

- Voldoire A, Sanchez-Gomez E, Salas y Mélia D, Decharme B and others (2013) The CNRM-CM5.1 global climate model: description and basic evaluation. Clim Dyn 40:2091-2121

Wilby RL, Charles SP, Zorita E, Timbal B, Whetton P, Mearns LO (2004) Guidelines for use of climate scenarios developed from statistical downscaling methods. IPCC, available at www.ipcc-data.org/guidelines/

Wood AW, Maurer EP, Kumar A, Lettenmaier DP (2002) Long-range experimental hydrologic forecasting for the eastern United States. J Geophys Res 107:D20, doi:10. 1029/2001JD000659

- Wood AW, Leung LR, Sridhar V, Lettenmaier DP (2004a) Hydrologic implications of dynamical and statistical approaches to downscaling climate model outputs. Clim Change 62:189-216

Submitted: June 30, 2014; Accepted: March 18, 2015

Proofs received from author(s): May 21, 2015 